Case Report

\title{
DIRECT INSERTION OF EUCHROMATIC MATERIAL FROM CHROMOSOME Y IN THE X-CHROMOSOME IN HYPOGONADOTROPIC HYPOGONADISMS WITH CROHN'S DISEASE
}

\author{
K.H. Ramesh, Q.H. QAZI, and Ram S. VeRmA* \\ Division of Genetics, The Long Island College Hospital-SUNY Health Science Center \\ at Brooklyn, NY 11201-5514, USA
}

\begin{abstract}
Summary The relationship between chromosomal abnormalities and Crohn's disease has not been established. Crohn's disease is associated with inflammation of the bowel, severe abdominal pain and chronic diarrhea. Its etiology is not known at present. A recessive gene with incomplete penetrance is thought to be a factor which does not follow simple mendelian inheritance. We report a case, where the euchromatin material of $Y$ chromosome (p11.1 p11.2) has been directly inserted into the long arm of the $\mathrm{X}$ chromosome (q21.2), and is assumed to be the most likely cause of hypogonadotropic hypogonadism in this patient. It could also be that the function of the testis-determining factor $(S R Y)$ has been disrupted due to the insertion, causing loss of testicular development.

Key Words chromosomes X and Y, SRY gene, Crohn's disease, hypogonadotropic hypogonadism
\end{abstract}

\section{INTRODUCTION}

Crohn's disease is an inflammatory gastro-intestinal disorder whose etiology at present is unknown (Ieso et al., 1992). The disease is associated with chronic inflammation, skin lesions, caseating granuloma, aphtoid (deep) ulceration, chronic diarrhea and severe abdominal pain (Podolsky, 1991). The development of stenosis and strictures in the bowel is a common feature of the disease (James et al., 1987). The immune status is often suppressed in these patients but there is no HLA association in sporadic or familial case (Surrenti et al., 1981). The mean ages of patients ranges from 15-45 years (Zolzer et al., 1992).

There is only one cytogenetic report of Crohn's disease with a Turner

Received April 7, 1997; Revised version accepted July 23, 1997.

* To whom correspondence should be addressed. 
phenotype and an unusual karyotype of $45, \mathrm{X}, / 47, \mathrm{XY},+13$ (Knudtzon et al., 1988). Translocations and deletions involving chromosomes 5 and 20 have also been reported in four cases (Eng et al., 1992). Although, the cytogenetic anomaly in these four cases may be a manifestation of myelodysplastic syndrome. A possible correlation between leukemia and chronic inflammatory bowel disease has also been suggested (Orii et al, 1991). Recently, Hugot and associates (1996) have identified an apparent Crohn's disease susceptibility locus on chromosome 16 and a possible involvement of a locus on chromosome $1 \mathrm{p}$ is suggested. Furthermore, Satsangi et al. (1996) provided strong evidence for the presence of susceptibility loci for both Crohn's disease and ulcerative colitis on chromosomes 3, 7 and 12. We report on a new case of Crohn's disease and hypogonadotropic hypogonadism with a $46, X \mathrm{X}, \operatorname{dir} \operatorname{ins}(\mathrm{X} ; \mathrm{Y})(\mathrm{q} 21.2 ; \mathrm{p} 11.1 \mathrm{p} 11.2)$ karyotype.

\section{CASE REPORT}

The patient is a 16 year old Afro-American male. At the time of his birth his mother (now deceased) was 39 years and his father was 33 years old. He has seven normal siblings whose ages range from 11-31 years. The patient had a six month history of progressive weight loss $(15 \mathrm{~kg}$ ), and peri-umbilical abdominal pain. At the time of admission his weight was $40 \mathrm{~kg}(<5$ th \%), height $160 \mathrm{~cm}(15$ th \%) and head circumference $54.5 \mathrm{~cm}$ (40th \%). Physical examination revealed upslanted eyes, ears $7 \mathrm{~cm}$ in length with a long philtrum, a highly arched palate and maloccluded teeth. There was no facial, axillary or public hair. The penis was small $(1.5 \mathrm{~cm})$ with hypoplastic scrotum and no palpable gonads either in the scrotum or in the inguinal canal. His speech was clear.

A hemogram suggested anemia of chronic infection. Thyroid function was normal. Plasma testosterone was $<20 \mathrm{ng} / 10 \mathrm{ml}$ (normal 300-700) are showed no response even after administration of HCG. Dehydroepiandroster one was $116 \mathrm{ng} /$ $100 \mathrm{ml}$ (normal 160-700). Serum FSH and LH were $<2$ and $0 \mathrm{mIU} / \mathrm{ml}$ respectively. A CT scan of the abdomen showed submucosal thickening of the proximal and mid small bowel accompanied by mesenteric and retroperitoneal adenopathy. The CT scan also showed the absence of right kidney and enlargement of the left kidney (compensatory hypertrophy). Testes were not visualized. Colonoscopic examination was normal, while enteroscopy showed mucosal changes in the distal esophagus, duodenum and jejunum. Thickened mucosal folds with nodules in the jejunum suggested pseudopolyp formation. Histological examination of biopsied material showed chronic inflammatory changes and noncaseating granuloma. Based on these finds Crohn's disease was diagnosed in this patient. Cytogenetic evaluation was requested because of hypogonadotropic hypogonadism. 


\section{MATERIALS AND METHODS}

Cytogenetic analysis of peripheral blood was according to standard protocols (Verma and Babu, 1995). FISH-technique was performed as per manufacturers specifications using the following probes: (a) spectrum green $X$ and spectrum orange $\mathrm{Y}$ whole chromosome paints [WCP] (Gibco-BRL, NY); (b) X coatasome with pseudoautosomal region of $T$ (Oncor, MD); and (c) Y WCP, spanning the euchromatic region (Cambio, UK).

Briefly, chromosomal DNA was denatured in $70 \%$ formamide $/ 2 \times \mathrm{SSC}(\mathrm{pH}$ 7.0) at $72^{\circ} \mathrm{C}$ and dehydrated in ethanol series. The probe mixures were heat denatured at $72^{\circ} \mathrm{C}$ followed by the immediate chilling of probes (a) and (b) while probe (c) was allowed to re-anneal at $37^{\circ} \mathrm{C}$ for $90 \mathrm{~min}$. Hybridization of the probes and chromosomal DNA at $37^{\circ} \mathrm{C}$ overnight was followed by post-hybridization washes in formamide $/ 2 \times \mathrm{SSC}(\mathrm{pH} 7.0)$ at various stringencies specified for each probe. Detection was by using FITC-avidin and the chromosomes counterstained with DAPI or propidium iodide/anti-fade. Twenty metaphases were analyzed and photomicrographs taken on a Kodak-Ektachrome 1600-ASA film, and also from the Oncor $3 \mathrm{CCD}$ cooled integrating camera.

\section{RESULTS AND DISCUSSION}

GTG banded metaphases revealed a normal 46,XY karyotype (Fig. IA). The presence of a very small penis and absence of the testes was suggestive of an abnormality involving the $\mathrm{Y}$ chromosome. Therefore, the FISH-technique was employed using $X$ (green) and $Y$ (orange) WCP which revealed the presence of $Y$ material (orange band) in the long arm of the $X$ chromosome (Fig. 1B). We used euchromatin Y WCP (probe c) to confirm that the $\mathrm{Y}$ material in the long arm (q21.2) of $X$ was euchromatic in nature (Fig. 1C). The $X$ coatasome probe showed that the pseudoautosomal region (PAR) of $\mathrm{Y}$ was intact indicating that the deletion probably occurred below the Par in band p11.2 (Fig. ID). In conjunction with the molecular findings, we modified the cytogenetic diagnosis to $46, \mathrm{XY}$, dir ins $(\mathrm{X} ; \mathrm{Y})(\mathrm{q} 21.2 ; \mathrm{p} 11.1 \mathrm{p} 11.2)$.

It is tempting to speculate that the insertion of $Y$ euchromatin material in the long arm of the $\mathrm{X}$ chromosome to be a de novo early-post-fertilization event. The deletion occurred in the $\mathrm{p}$ arm, proximal to the pseudoautosomal region of the $\mathrm{Y}$ chromosome and most likely involved the testis-determining factor-SRY [TDF$S R Y]$ region. The insertion of the $\mathrm{Y}$ euchromatin material in the $\mathrm{q}$ arm of $\mathrm{X}$, probably resulted in the disruption of the TDR-SRY gene function. There is considerable evidence that the testis-determination factor a $35 \mathrm{~kb}$ sequence is located adjacent to the pseudoautosomal boundary of the $\mathrm{Y}$ chromosome. It is well documented that the $S R Y$-gene encodes a factor that is necessary for the 

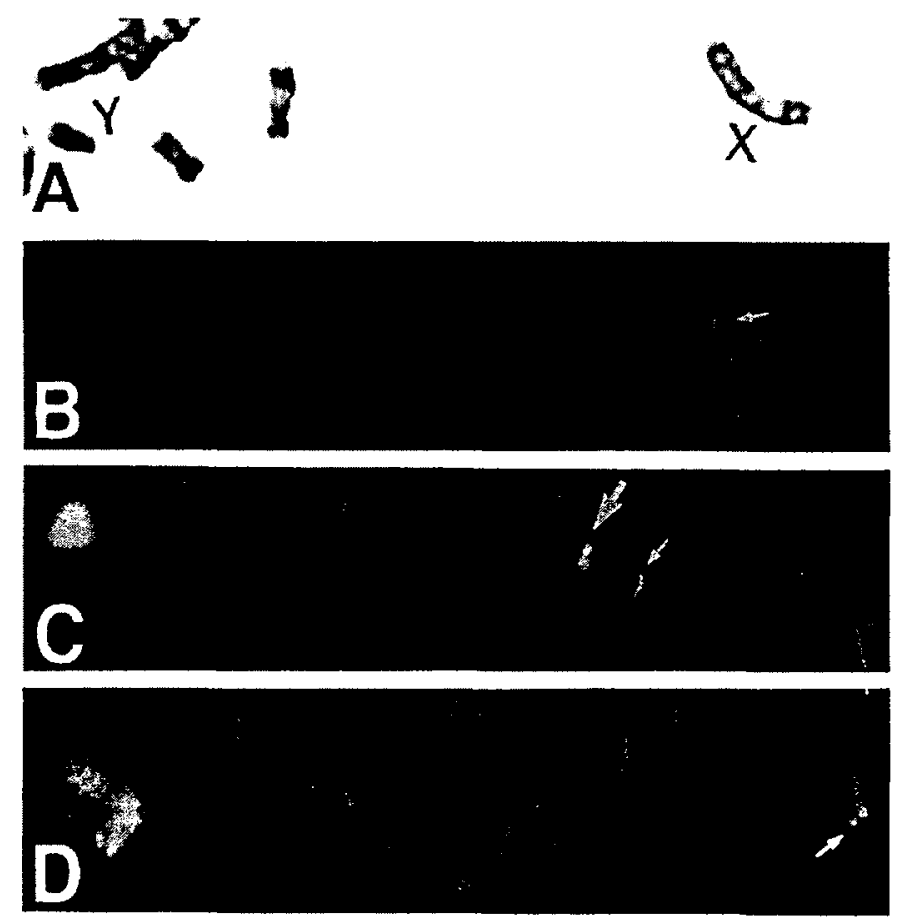

Fig. 1. A: GTG banded partial metaphase showing chromosome $X$ and $Y$. B: Chromosome 2 (spectrum green) and $Y$ (spectrum orange) whole chromosome paint probes show the direct insertion of $Y$ chromosome material (arrow) into the long arm of the $\mathrm{X}$ chromosome. $\mathrm{C}$ : Chromosome $\mathrm{Y}$ euchromatin specific probe showing that the insertion is euchromatic (small arrow) in nature. Hybridization signal is seen on the pseudoautosomal region of $X$ (large arrow). Chromosome $Y$ is seen at far left. $D$ : $X$ coatasome probe showing the pseudoautosomal region of $Y$ (small arrow) to be intact. Chromosome $X$ is seen at far left (see text).

initiation of testis-development (Berta et al., 1990; Goodfellow and Darling, 1988; Hawkins et al., 1992; Koopman et al., 1991; McElreavy et al., 1992; Sinclair et al., 1990). It is possible that the direct insertion of $Y$ euchromatin material at band q21.2 of the $X$ chromosome is related to the presence of hypogonadotropic hypogonadism in this case. Alternatively, this chromosomal imbalance may be an accidental finding and have nothing to do with Crohn's disease. We were unable to contact the patient to arrange their return for further molecular investigation.

Crohn's disease is an autosomal recessive disorder and the familial pattern does not reflect a simple mendelian inheritance (McKusick, 1994). It has been suggested that a recessive gene with incomplete penetrance is responsible for susceptibility to Crohn's disease (Kuster et al., 1988). The risk of developing Crohn's disease in first degree relatives of these patients is about 10 fold (Orholm et al., 1991). The probability of the presence of a susceptibility gene for Crohn's 
disease remains. Recently, involvement of a locus on chromosome 1 and 16 has been proposed by linkage analysis (Hugot et al., 1996). Could there be another loci on $\mathrm{Xq}$ ?

Acknowledgments We thank Chandrika Sreekantaiah and Michael J. Macera for helpful comments. The suggestions given by Dr. Nick Triantafillou on the case report is greatly appreciated. We thank Michael Lazar for the photographic assistance. Our thanks to Nany CaraballoGuerra and Mark A. R. Sealy for typing the manuscript.

\section{REFERENCES}

Berta P, Hawkins JR, Sinclair AH, Taylor A, Grifiths B, Goodfellow PN, Fellous M (1990): Genetic evidence equating $S R Y$ and the testis-determining factor. Nature 348: 448-450

Eng C, Farraye FA, Shulman LN, Peppercorn MA, Krauss CM, Connor JM, Stone RM (1992): The association between the myelodysplastic syndromes and Crohn disease. Ann Intern Med 117: $661-662$

Goodfellow PN, Darling SM (1988): Genetics of sex determination in man and mouse. Development 102: $251-258$

Hawkins JR, Taylor A, Berta P, Levillers J, Van der Auwera B, Goodfellow P (1992): Mutational analysis of $S R Y$ : nonsense and missense mutations in XY sex reversal. Hum Genet 88: 471474

Hugot J-P, Laurent-Puig P, et al. (1996): Mapping of a susceptibility locus for Crohn's disease on chromosome 16. Nature 379: 821-823

Ieso Y, Hibi T, Watanabe M, Takaishi H, Hosoda Y, Hayashi A, Ohara M, et al. (1992): The mechanism of action of serum immunosuppressive factor in Crohn's disease: It blocks the growth of mitogen-stimulated lymphocytes in early $G_{1}$ phase through an inhibition of transferrin receptor expression. J Clin Lab Immunol 38: 15-27

James SP, Stober W, Quinn TC, Danovithch SH (1987): Crohn's disease. New concepts of pathogenesis and current approaches to treatment. Dig Dis Sci 32: 1297-1310

Knudtzon J, Ledaal P, Middelthon-Moe M, Aarskog D (1988): 45X/47XY, 13 mosaicism and Crohn's disease. Acta Paediatr Scand 77: 922-924

Koopman P, Grubbay J, Vivian N, Goodfellow P, Lorell-Badge R (1991): Male development of chromosomally female mice transgenic for SRY. Nature 351: 117-121

Kuster W, Pascoe L, Purrmann J, Funk S, Majewksi F (1988): The genetics of Crohn disease: complex segregation analysis of a family study with 265 patients with Crohn disease and 5387 relatives. Am J Med Genet 32: 105-108

McElreavy K, Vilian E, Abbas N, Costa JM, Souleyreau N, Kucheria K, Bouchekkine G, Thibault E, Flammenat F, Fellous M (1992): XY sex reversal associated with a deletion $5^{\prime}$ to the SRY "HMG" box in the testis-determining-region. Proc Natl Acad Sci USA 89: 11016-11020

McKusick VA (1994): Mendelian inheritance in man. In: Catalogs of autosomal dominant, autosomal recessive and X-linked phenotypes. 11 th ed. The Johns Hopkins University Press, Baltimore, pp 2169-2170

Orholm M, Munkhom P, Langholz E, Neilsen OH, Sorensen TIA, Binder V (1991): Familial occurrence of inflammatory bowel disease. $N$ Engl J Med 324: 84-88

Orii S, Sugai I, Nakano O, Yoshinari H, Sato S (1991): Acute promyelocytic leukemia in Crohn's disease. J Clin Gasteroenterol 12: 325-327

Podolski DK (1991): Inflammatory bowel disease. N Engl J Med 325: 928-937

Satsangi J, Parkes M, Louis E, et al. (1996): Two stage genome-wide search in inflammatory bowel disease provides evidence for susceptibility loci on chromosomes 3,7 and 12 . Nature Genet 14: 199-202

Sinclair AH, Berta P, Palmer MS, Hawkins JR, Griffiths BL, Smith MJ, Foster JW, et al. (1990):

Vol. 42, No. 4, 1997 
A gene from the human sex-determining region encodes a protein with homology to a conserved DNA-binding motif. Nature 346: 240-244

Surrenti C, Ramarli C, Cussini A, et al. (1981): Studies of cell-mediated immunity in patients with Crohn's disease. Hepato-gastroenterology 28: 157-159

Verma RS, Babu A (1995): Human chromosomes. Principles and techniques. McGraw-Hill, New York

Zolzer F, Streffer C, Beuningen DV, Pelzer T, Gross E, Eigler FW (1992): Flow cytometric analysis of colorectal mucosa from patients with Crohn's disease ulcerative colitis and cancer. Oncology 49: 359-362 